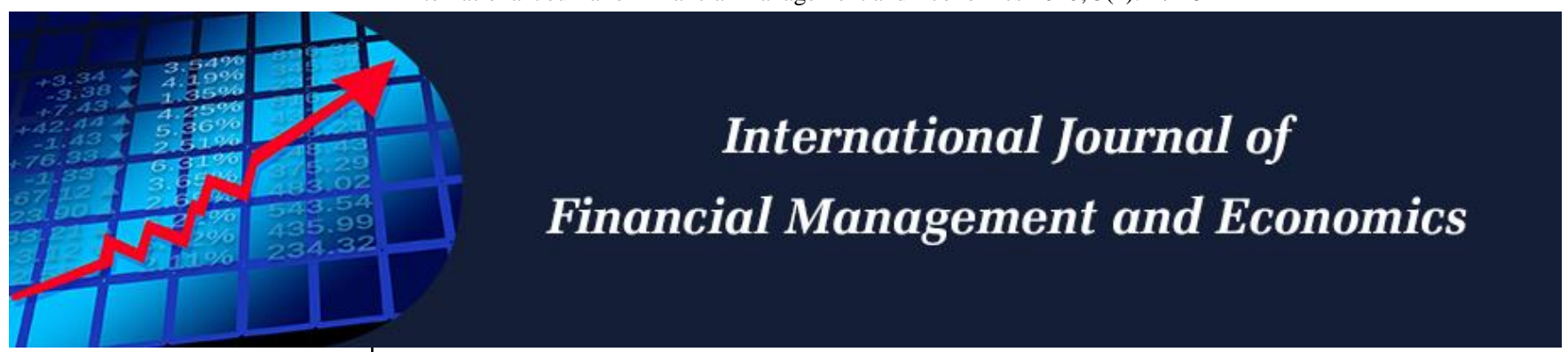

P-ISSN: 2617-9210 E-ISSN: $2617-9229$ IJFME 2020; 3(2): 17-23 Received: 16-05-2020 Accepted: 07-06-2020

Joshua Benson Nadiyasu Department of Accounting, Adamawa State University, Mubi, Nigeria
Corresponding Author: Joshua Benson Nadiyasu Department of Accounting, Adamawa State University, Mubi, Nigeria

\section{Political connections and firm performance in non- financial firms listed on Johannesburg stock exchange}

\author{
Joshua Benson Nadiyasu
}

DOI: $\underline{\text { https://doi.org/10.33545/26179210.2020.v3.i2.50 }}$

\begin{abstract}
This study concerns with how political connections affect firm performance. Extant literature in the subject presented mixed and inconclusive findings. The aim of the study was two fold: to examine the effect of political connections on firm performance and to find out whether or not different types of political connections affect firm performance differently. Fifty (50) firms listed on Johannesburg Stock Exchange (JSE) were used as the sample size of the study based on a study period from 2012 to 2018. A dynamic regression using the GMM estimation technique was used to test the relationship. The results indicate that in general, political connections positively affect firm performance, but not all types of such connections affect firm performance. It was recommended that political connections should be discouraged in non government linked companies because of the instability of such types of connections. Government linked companies on the other hand, should explore other types of political connections in order to enhance performance.
\end{abstract}

Keywords: political connections, GMM, firm performance, JSE

\section{Introduction}

There has been an increasing body of literature on the relationship between firms' political connections and their performance. The traditional wisdom is that political connections provides a solid ground for firm performance. A central part supporting this argument is that such connections provide the a firm with many forms of institutional support to access information and resources (Saeed, Belghitar, \& Clark, 2014) ${ }^{[27]}$. This includes: accessing government support and contract (Sojli \& Tham, 2017; Faccio, Masulis, \& McConnell, 2006) ${ }^{[30,12]}$, accessing bank financing and reduced cost of capital (Claessens Feijen, \& Laeven, 2008) ${ }^{[9]}$, slack tax enforcement and lower tax burden (see, Adhikari, Derashid, \& Zhang, 2006) ${ }^{[1]}$ and other slack enforcement of regulations (Firth, Rui, \& Wu, 2011) ${ }^{[13]}$. If these privileges are effectively used, they could be translate into better firm performance see (Wu, Li, Ying \& Chen, 2018) ${ }^{[32]}$. Therefore politically connected firms are strategically positioned for better firm performance as compared to non politically connected firms.

However, the traditional wisdom has been refuted by some researchers who argued that political connections could negatively impact on firm performance. Some of the arguments advanced include; (1) political connections potentially leads oversupply of loan thereby increasing financial burden (Ling, Zhou, Liang Song \& Zeng; 2016) ${ }^{[19]}$. (2) Rent seeking and extraction could be the major interest of connected politicians rather than firm value maximization (Shleifer \& Vishny 1998) ${ }^{[29]}$. (3) Political interference through appointment of incompetent politicians to run connected firms ultimately affects the performance of such firms, see (Boubakri, Cosset, \& Saffar, 2012) ${ }^{[3]}$. Additionally, politically connected firms have the propensity of undertaking risky investments and have poor financial management practices (Hung, Kim, \& Li, 2018) ${ }^{[16]}$. They are therefore prone to corporate failures. Such corporate failures could lead to financial losses and loss of jobs thereby having a negative effect on firm performance.

South Africa is one of the leading economies in Africa and has experienced different political crisis in recent years. It has also experienced many corporate scandals in the past decade as reported by (Business insider, South Africa, 2020). It is therefore imperative to understand how political connections affect firm performance in the South African context. 
This is so because there are limited studies in this area that are specific to the South African setting. Past studies on the relationship between political connections and firm performance are mixed and inconclusive. While some found positive relationship, see for instance: (Niessen and Ruenzi, 2009 \& Wu, Li, Yin \& Chen, 2018) ${ }^{[22,32]}$ others conversely found a negative relationship. See for instance (Chen, Liao, Lin \& Yen; 2018 \& Ling, et al. 2016) ${ }^{[32,19]}$. There are also studies that found insignificant relationship, see for instance (Sami, Rahnavard \& Tabar (2019) ${ }^{[28]}$. Is noteworthy to say that, there are different studies having different definitions for both political connections and firm performance, there are also differences in political systems and types of political connections across the globe. Moreover, market developments differ from one country to another. Hence, findings on political connections-firm performance nexus from a particular country may not be applicable to another. Even though there are many studies on political connections and firm performance nexus, this study however, differs from previous studies in particular ways: (1) while most past studies consider political connections through both past and incumbent politicians, this study only defines one as a politician if and only if he or she holds a high political office in south Africa during the period of the study. (2) The study employed dynamic approach using the GMM estimation technique which was seldomly used by past studies. (3) It also outlined three different types of political connections namely: connections through directors, connections through large shareholders and connections through government linked companies (GLCs). This classification differs from most past studies that have more or less types of connections or in some cases no specific types.

Therefore, the mixed empirical evidences and the possible explanations highlighted above provide a conundrum, which requires further investigation. With this situation one may ask the following questions. Firstly, what will be the effect of political connections on firm performance of firms listed on Johannesburg Stock Exchange (JSE)? Secondly, do different types of political connections have same effect on performance of firms listed on JSE? To answer these questions, two objectives were proposed (1) To examine the effect of political connections on firm performance of firms listed on JSE and (2) to ascertain whether or not different types of political connections affect firm performance differently.

In order to achieve these objectives, I structured the paper as follows. The first section is the introductory part of the paper, the second section deals with literature review covering the underpinning theory and review of empirical studies. The third sections deals with the methodology. The fourth section covers the GMM estimation results and discussion. Finally, the fifth section deals with conclusion

\section{Theoretical background and empirical review 2.1 Theoretical background}

Based on Resource Dependency Theory (RDT) propounded by Pfeffer and Salancik (1978) ${ }^{[24]}$. RDT is concerned with organizational behaviour, which is affected by need for external resources they utilize. It follows that, in the bid to get competitive advantage over others, firms have to apply different strategies to get access to scarce resource it utilizes. Government is the main source of external resources (Wu, Li, Ying \& Chen, 2018) ${ }^{[32]}$ especially in emerging like economies where weak market laws exist (Kuo \& Yu, 2017) ${ }^{[17]}$.

Consequently, firms go into political connections in order to have access to these vital and scarce resources. These connections help the firms to manage uncertainties and interdependence.

\subsection{Review of empirical studies}

Studies abound that found a positive relationship between political connections and firm performance. Niessen and Ruenzi (2009) ${ }^{[22] ~ i n v e s t i g a t e d ~ t h e ~ p o l i t i c a l l y ~ c o n n e c t e d ~}$ firms in Germany for the period 2006-2007. They tested among other things the effect of firms' political connections to members German parliament and their performance as compared to their non connected counterparts. Their findings revealed that politically connected firms have slightly better accounting performance and significantly higher market performance than non connected firms. The study however, majors on political connections through members of parliament without taking into consideration other types of political connections.

Prior to this, a study was carried out by Li, Meng, Wang and Zhou (2008) ${ }^{[18]}$, their study examined how affiliation to Chinese Communist Party (CCP) influences the business operations of private enterprises in China. Using a survey research design, they found after controlling for human capital and other appropriate variables that $\mathrm{CCP}$ membership has a positive effect on firm performance of private enterprises in China. This study also only considered one type of political connections that is, CCP membership. Recently, a study was conducted by Wong and Hooy (2018) [31] in Malaysia, their aim was to find out whether or not different types of political connections affect firm performance differently. After considering four types of political connections, they found that overall, political connections affect firm performance positively, however, there are differences in the way and manner the different types of connections affect performance. They document that a positive relationship exit between political connection through government linked companies (GLCs) and through directors with firm performance, but no such relationship exist if such connections are through businessmen and family members. They argue that connections through GLCs and politicians and board members are more stable than connections through businessmen and family members. One of the issues in this study is that the researchers did not consider a possible dynamic relationship.

Another interesting study was conducted by Ling, Zhou, Liang, Song, \& Zeng (2016) ${ }^{[19]}$. They used a sample of 103 listed real estate firms in China, for the period 1998- 2012. They categorized the political connections based on Chinese hierarchical rank system (seven political ranks). This categorization was for firms' board members and Chief Executive officers CEOs. Their results indicated a negative relationship between political connections and Return on Assets (ROA). They argue that undertaking political connections could be a risky investment. They further pointed out that stronger political connections are financed with more long term bank loan and more likely to over invest.

Similarly, Omonona \& Oni (2019) ${ }^{[23]}$ examined the relationship between political affiliations and performance of firms in South African mobile telecommunication industry. They conducted a survey on population drawn 
from selected mobile telecommunication organization and their result indicated that political connections affects both performance and non performance of mobile telecommunication firms. They therefore suggested a reduction in frequent cabinet reshuffle while ensuring political integration and government stability.
Table 1 below gives a summary of empirical studies on political connections and firm performance. The table indicates the authors, country of research, period of research, measurements of main variables of interest, method and results.

Table 1: Selected empirical studies on political connections and firm performance relationship

\begin{tabular}{|c|c|c|c|c|c|c|c|}
\hline \multirow{2}{*}{$\mathbf{S} / \mathbf{N}$} & \multirow{2}{*}{ Author(s) } & \multirow{2}{*}{ Country } & \multirow{2}{*}{ Period } & \multicolumn{2}{|c|}{$\begin{array}{l}\text { Variables } \\
\end{array}$} & \multirow{2}{*}{ Method } & \multirow{2}{*}{ Results } \\
\hline & & & & Political Connections & Firm Performance. & & \\
\hline 1 & $\begin{array}{l}\text { Saeed, Belghitar and } \\
\text { Clark (2016) }\end{array}$ & Pakistan & $2002-2010$ & Connections through Directors & $\begin{array}{l}\text { ROA and ROE, } \\
\text { Tobins'q }\end{array}$ & $\begin{array}{l}\text { FE,Heckman 2stage } \\
\text { regression, GMM }\end{array}$ & + \\
\hline 2 & $\begin{array}{c}\text { Wu, Wu Zhou \&Wu } \\
(2012)\end{array}$ & China & $1999-2007$ & Connections through Managers & Tobins'q & $\begin{array}{l}\text { OLS and Heckman } \\
\text { regression }\end{array}$ & $\begin{array}{l}\text { Private PC out } \\
\text { perform SOEs }\end{array}$ \\
\hline 3 & \begin{tabular}{|c|} 
Li, Meng, Wang \& \\
Zhou (2008) \\
\end{tabular} & China & 2002 & $\begin{array}{c}\text { Party membership of } \\
\text { entrepreneurs }\end{array}$ & ROA \& ROE & OLS & $x_{2}$ \\
\hline 4 & \begin{tabular}{|c|} 
Zhang, Li, Zhou \& Zhou \\
(2013)
\end{tabular} & China & $2007-2010$ & $\begin{array}{c}\text { Government background of } \\
\text { firms' executives } \\
\end{array}$ & ROA & Regression analysis & + \\
\hline 5 & \begin{tabular}{|c|} 
Chen, Liao, Lin \& Yen \\
$(2018)^{[32]}$
\end{tabular} & $\begin{array}{l}\text { Multi } \\
\text { country }\end{array}$ & $\begin{array}{c}\text { 2004- 2006, } \\
\text { 2007-2009 }\end{array}$ & Politically connected CEO'S & ROA, ROE & Panel data model & - \\
\hline 6 & $\begin{array}{l}\text { Hung,Jiang, Liu, Tu, } \\
\text { \&Wang (2017) }\end{array}$ & China & 2007-2014 & $\begin{array}{l}\text { CEO'S with former } \\
\text { government experience }\end{array}$ & ROA & Panel data model & + \\
\hline 7 & $\begin{array}{c}\text { Chung, Byun, \& Young } \\
(2019)^{[8]}\end{array}$ & South Korea & $1998-2013$ & $\begin{array}{l}\text { Previous or serving politician } \\
\text { or public servant as a director } \\
\text { or top officer }\end{array}$ & ROA \& Tobins'q & Fixed effect & + \\
\hline 8 & \begin{tabular}{|c|} 
Muttakin, Monem, \\
Khana, \& Subramaniam \\
$(2015)^{[21]}$
\end{tabular} & Bangladesh & 2005-2009 & Connected family firms & ROA \& Tobins'q & OLS & + \\
\hline 9 & \begin{tabular}{|c|} 
Niessen \& Ruenzi \\
$(2009)^{[22]}$
\end{tabular} & Germany & 2006-2007 & Connections through delegates & $\begin{array}{c}\text { ROA, ROI, P/E ratio } \\
\text { \& Tobins'q }\end{array}$ & Panel data model & + \\
\hline 10 & Wong \& $\underset{[31]}{\text { Hooy (2018) }}$ & Malaysia & 2002-2016 & $\begin{array}{c}\text { Four types of political } \\
\text { connections }\end{array}$ & ROA \& Tobins'q & Panel data model &,+ 0 \\
\hline 11 & $\begin{array}{c}\text { Wu, Li, Ying \& Chen } \\
(2018)^{[32]}\end{array}$ & China & $2005-2012$ & $\begin{array}{l}\text { Connected firm executives } \\
\text { (CEOs) }\end{array}$ & ROA & $\begin{array}{c}\text { Pooled cross sectional } \\
\text { regression }\end{array}$ & + \\
\hline 12 & $\begin{array}{l}\text { Cao, Lemmon, Pan, } \\
\text { Qian, \& Tian (2018) }\end{array}$ & China & $2005-2011$ & CEOs of SOEs & $\begin{array}{l}\text { ROA \& ROE, } \\
\text { Tobins'q }\end{array}$ & $\begin{array}{l}\text { Logistic regression } \\
\text { and } 2 \text { SLS regression } \\
\end{array}$ & + \\
\hline 13 & $\begin{array}{l}\text { Ling, Zhou, Liang, } \\
\text { Song, \& Zeng }\end{array}$ & China & $1998-2012$ & Seven political ranks & Tobins'q \& ROA & $\mathrm{FE}$ & - \\
\hline 14 & $\begin{array}{l}\text { Sami, Rahnavard \& } \\
\text { Tabar (2019) }{ }^{[28]} \\
\end{array}$ & Iran & 2015 & Political ties & Balance scorecard & $\begin{array}{l}\text { Applied research and } \\
\text { descriptive survey }\end{array}$ & 0 \\
\hline 15 & $\begin{array}{l}\text { Maaloul, Chakroun, \& } \\
\text { Yahyoui }(2018)^{[20]}\end{array}$ & Tunisia & 2012-2014 & $\begin{array}{c}\text { Connections through firms' } \\
\text { officers and directors }\end{array}$ & Tobins'q \& ROA & $\begin{array}{c}\text { 2SLS regression and } \\
\text { OLS }\end{array}$ & + \\
\hline 16 & Amonoma \& Oni (2019) & South Africa & & $\begin{array}{l}\text { Senior and management staff } \\
\text { response }\end{array}$ & & $\begin{array}{c}\text { Survey research } \\
\text { design }\end{array}$ & + \\
\hline
\end{tabular}

Source: Author's compilation, 2020

NB: ROA =return on assets, ROE = return on equity, ROI = return on investment, $\mathrm{P} / \mathrm{E}$ ratio = price/earning ratio, $\mathrm{FE}=$ fixed effect, $\mathrm{SOEs}=$ state owned enterprises, GMM = generalized method of moments, OLS = ordinary least square, $\mathrm{PC}=$ political connections, $2 \mathrm{SLS}$ regression $=$ two stage least square regression

\section{Methodology}

\subsection{Data and variable}

As earlier stated, the objectives of this study were twofold, firstly is to examine the relationship between political connections and firm performance and secondly, to find out if the relationship differ with differences in types of political connections. All variables in this paper were selected based on previous studies on political connections and firm performance, see for instance: tobins'q: (Chung et al., 2019; Saeed, et al., 2018; and Muttakin et al., 2015) ${ }^{[8,21]}$. Firm size, see (Wu, et al., 2018; Guo, Li, \& Zhong, 2019) ${ }^{[32,14]}$ and board independence: (Gou, Li and Zhong 2019; and Maaloul et al., 2018) ${ }^{[14,20]}$. The study used a sample of 50 non financial services companies listed on (JSE). The sample of 50 firms was select based on availability of complete data. The study period was from 2012 to 2018 .

The data on the dependent variable tobins'q was retried from data stream and was calculated as follows market value by company divided by common shareholders' equity. I extracted the data on political connections from the firms' annual reports and list of members of parliaments downloaded from the website of the parliament of the republic of south Africa. A company is said to be politically connected if any of its directors or large share holders (having at least $10 \%$ voting right) is a member of parliament, minster or prime minister of the republic of South Africa or a close relative (parent, child, sibling and spouse) of a member of parliament, minister, or prime minister or the company has a link to the government which has at least a $10 \%$ voting right through any of its agencies.

The data on political connections were painstakingly extracted from the two sources and, where it was difficult to establish the certainty of political connections, a general search on the internet was conducted to avoid errors. A combination of all these political connections was used to estimate the model for the first objective. From this also can be seen, three different types of political connections namely: connection through board of directors, connection through large share holders (owners) and connection through GLCs. The three types of connections were used to examine their individual effect on firm performance. Firm size and board independence were used as control variables calculated as natural log of total assets and percentage of independent directors based on the total number of directors respectively. 
Table 2: Descriptive statistics

\begin{tabular}{|c|c|c|c|c|c|c|c|}
\hline $\mathbf{S} / \mathbf{N}$ & Variable & Measurement & Mean & Std. Dev. & Min & Max & Obs \\
\hline 1 & Tobins'Q & Market value by company/common share holders' equity & 0.003 & 0.003 & 0.000 & .020 & 350 \\
\hline 2 & LTobins'Q & Lag of tobins'q & 0.003 & 0.003 & 0.000 & .020 & 300 \\
\hline 3 & PCDirectors & Connections through directors & 0.123 & 0.329 & 0 & 1 & 350 \\
\hline 4 & PCowners & Connection through large shareholders & 0.066 & 0.248 & 0 & 1 & 350 \\
\hline 5 & NonPCglcs & 3 and 4 & 0.180 & 0.399 & 0 & 1 & 350 \\
\hline 6 & PCglcs & Government linked companies & 0.446 & 0.498 & 0 & 1 & 350 \\
\hline 7 & PConnections & 5 and 6 & 0.554 & 0.499 & 0 & 1 & 350 \\
\hline 8 & Bindependence & Percentage of independent directors & 0.543 & 0.205 & 0 & 1 & 350 \\
\hline 9 & Lnfsize & Ln of Total assets & 16.548 & 1.286 & 12.297 & 219.851 & 350 \\
\hline
\end{tabular}

Table 2 shows the descriptive statistics of all main variables and how they were measured. The average, standard deviation, minimum, maximum and number of observations are also displayed. The table revealed that there was an average increase in firm performance proxy of Tobins' $Q$ by 0.3 percent during the period of the study. This shows an overall law performance with least performing firms gaining almost nothing and performing firms increasing performance by 2 percent. Average political connections through directors and large shareholders increased over the period by 12 percent and 6.6 percent respectively, while that of government linked companies increase 44.6 percent. Overall, political connections increased by 55.6 percent. Average board independence increased by 54.3 percent while the natural $\log$ of total assets increased by 1654 percent.

\subsection{Method of estimation}

Based on past studies, two most common proxies used for firm performance are Tobins'Q and ROA. These variables have been selected based on theory and empirical findings of past studies. However, based on the data obtained from data-stream, there were some missing observations for ROA hence Tobins'Q only was use. It is note worthy to state that, this section presents the estimation procedure of the study. In line with previous literature and to control for the problems of possible endogeneity, auto-correlation and heteroskedasticity that may occur in a dynamic panel regression, I adopted the Generalized Method of Moments (GMM) estimation technique proposed by Arellano and Bond (1991) ${ }^{[2]}$ and Roodman (2009) ${ }^{[26]}$. A problem of possible endogeneity occurs where lagged dependent variable is added in a regression model see for instance (Danjuma and Nadiyasu, 2020) ${ }^{[10]}$. It is therefore believed that the OLS, Random Effect and Fixed effect models are unable to take care of simultaneity and endogeneity bias, as revealed by (Arellano and Bond, 1991) ${ }^{[2]}$. Hence the following dynamic model was proposed.

$\pi_{i t}=\beta_{o}+\beta_{1}$ tobins $Q_{i t-1}+\beta_{2} \pi_{i t-1}+\sum \beta_{3} X_{i t}+y+d_{t}+\varepsilon_{i t}$
Where; $\pi_{i t}$ represents tobins'Q (proxy of firm performance), ${ }^{\text {tobins' }}{ }_{i t-1}$ represents tobins' $Q$ of past year, ${ }^{i t-1}$ represents previously accumulated performance. $X_{i t}$ is the vector of the control variables (board independence and firm size (natural $\log$ of total assets)). ${ }^{y_{i}}$ represents the the firms' characteristics that are time invariant and not observable, but controllable with the explanatory variable. $d_{t}$ represents the year dummy that controls the time effect. ${ }^{\varepsilon_{i t}}$ represents the error term which changes based on time and firm, while, $\beta_{1}$ and $\beta_{2}$ represent regression coefficient showing the persistence of performance and regression coefficient explaining the past political connections on current political connections.

As stated earlier, when the lag of the dependent variable has been included in the regression as seen in the equation above, the problem of endogeneity occurs. Previous studies used the GMM estimation technique to solve the this problem. This study therefore adopts the GMM techniques to test the hypotheses on (1) the effect of political connections on firm performance. (2) The variation in the relationship in (1) where exists different types of political connections.

\section{Estimation result}

The correlation matrix in table 3 shows no problem of multicollinearity among the variables of interest. Because the few coefficient above are 0.5 are those that contain some elements of the corresponding variable in them and will not be regressed together except for the lagged dependent variable. While the correlation matrix shows a positive association between overall political connections and political connections through GLCs with firm performance, it also revealed a negative association between others namely: board independence, firm size and other types of political connections. Apart from lagged dependent variable, the strongest correlation with firm performance is the connection through the GLCs $(0.2138)$ while the weakest is connection through directors $(-0.1739)$.

Table 3: Correlation matrix

\begin{tabular}{|c|c|c|c|c|c|c|c|c|c|}
\hline & Tobinsq & Ltobinsq & Pcdir. & Pcown. & Nonpcglcs & Pcglcs & Pconnections & Bindependence & Lnfsize \\
\hline Tobinsq & 1.0000 & & & & & & & & \\
\hline Ltobinsq & 0.8598 & 1.0000 & & & & & & & \\
\hline Pcdir & -0.1739 & -0.1823 & 1.0000 & & & & & & \\
\hline Pcown & 0.0229 & 0.0365 & 0.0764 & 1.0000 & & & & & \\
\hline Nonglcs & -0.1319 & -0.1308 & 0.8132 & 0.6032 & 1.0000 & & & & \\
\hline Pcglcs & 0.2138 & 0.1377 & -0.0204 & -0.0522 & -0.0732 & 1.0000 & & & \\
\hline Pconnections & 0.1345 & 0.0563 & 0.3356 & 0.2378 & 0.4048 & 0.8041 & 1.0000 & & \\
\hline Bindepende e & -0.0554 & -0.0559 & 0.0256 & -0.0175 & -0.0209 & 0.1425 & 0.0495 & 1.0000 & \\
\hline Lnfsize & -0.1639 & -0.1406 & 0.1414 & -0.0704 & 0.0694 & 0.0044 & 0.0402 & 0.1301 & 1.0000 \\
\hline
\end{tabular}


From the estimation result in table 4, the level instrument are valid since the number of instruments are less than the number of groups in each of the models hence, no problem of too many instruments see (Roodman, 2009) ${ }^{[26]}$. Also the Hansen statistics showed insignificant p-values in all the models which means valid over-identifying restrictions of all instruments. Furthermore, time dummy variables have been introduced in order to control for cross-sectional dependency and avoid time varying shocks in the model.
This was used by previous researchers like: (Danjuma et al., 2020 \& Ding, Li and $\mathrm{Wu}, 2018)^{[10,30]}$. Finally, the second order auto-correlation result of Arellano and Bond are within the acceptance level. This indicates no autocorrelation problem. Therefore, since all instruments and the model specification must be valid to fulfil the requirements of the GMM estimation technique, I argue that the employment of GMM technique in this study was also in place.

Table 4: The effect of political connections on firm performance using one step system GMM estimation

\begin{tabular}{|c|c|c|c|c|c|}
\hline \multirow{2}{*}{ Variables } & (1) & (2) & (3) & (4) & (5) \\
\hline & Tobins'q & Tobins'q & Tobins'q & Tobins'q & Tobins'q \\
\hline \multirow{2}{*}{ L tobins'q } & $0.822 * * *$ & $0.842 * * *$ & $0.830 * * *$ & $0.837 * * *$ & $0.815 * * *$ \\
\hline & $(0.0870)$ & $(0.0866)$ & $(0.0872)$ & $(0.0871)$ & $(0.0881)$ \\
\hline \multirow{2}{*}{ P connections } & $0.000321 * *$ & & & & \\
\hline & $(0.000157)$ & & & & \\
\hline \multirow{2}{*}{ P cdir } & & $-6.61 e-05$ & & & \\
\hline & & $(0.000261)$ & & & \\
\hline \multirow{2}{*}{ Pcown } & & & $-9.49 \mathrm{e}-05$ & & \\
\hline & & & $(0.000306)$ & & \\
\hline \multirow{2}{*}{ Nonglcs } & & & & -0.000107 & \\
\hline & & & & $(0.000212)$ & \\
\hline \multirow{2}{*}{ Pcglcs } & & & & & $0.000346^{*}$ \\
\hline & & & & & $(0.000182)$ \\
\hline \multirow{2}{*}{ B independence } & 0.000342 & 0.000377 & 0.000397 & 0.000391 & 0.000261 \\
\hline & $(0.000473)$ & $(0.000498)$ & $(0.000503)$ & $(0.000502)$ & $(0.000467)$ \\
\hline \multirow{2}{*}{ Lnfsize } & $-0.000234 *$ & $-0.000224 *$ & $-0.000231^{*}$ & $-0.000225^{*}$ & $-0.000231 *$ \\
\hline & $(0.000122)$ & $(0.000112)$ & $(0.000119)$ & $(0.000115)$ & $(0.000121)$ \\
\hline \multirow{2}{*}{ Constant } & 0 & 0 & 0 & 0 & 0 \\
\hline & $(0)$ & $(0)$ & $(0)$ & $(0)$ & $(0)$ \\
\hline No. of instruments & 28 & 29 & 29 & 29 & 29 \\
\hline Observations & 300 & 300 & 300 & 300 & 300 \\
\hline No. groups & 50 & 50 & 50 & 50 & 50 \\
\hline Year dummy & yes & yes & yes & yes & yes \\
\hline Hansen stat. & 0.123 & 0.123 & 0.127 & 0.233 & 0.119 \\
\hline $\mathrm{AR}(1)$ & 0.002 & 0.003 & 0.003 & 0.003 & 0.003 \\
\hline $\mathrm{AR}(2)$ & 0.119 & 0.256 & 0.246 & 0.128 & 0.125 \\
\hline
\end{tabular}

Robust standard errors in parentheses $* * * p<0.01, * * p<0.05, * p<0.1$

Table 4 above presents five different models with robust standard errors. The first model is the general model consisting of the three different types of political connections used in this study. From this general model, it revealed that the coefficient of past performance is positive at 1 percent level of significance. This means that higher performance achieved the previous year led to higher performance in the current year. It suggests that a firm's ability to achieve higher performance in the future potentially depends on its ability to positively perform in the current year. The result also shows that a unit increase in current year's firm performance might lead to 0.82 unit increase in future performance. The significance level remains almost the same regardless of the differences in political connections.

Furthermore, the general model indicates that the coefficient of all the three types of political connections combined together is positively significant at 5 percent. Meaning that political connections significantly increases firm performance. This findings agrees with that of Wong and Hooy (2018) [31] who found that political connections (through directors, GLCs, business men, family ownership) jointly have positive effect on firm performance. This however contradicts the findings of Chen, et al. (2018) ${ }^{[14]}$. Who found a negative relationship between politically connected CEOs and firm performance. While this is clear, it is also clear that not all the types of political connections affect firm performance in the same way. Columns (2), (3) and (4) representing political connections through directors, large shareholders and a combination of both (political connections through director and large shareholders) respectively revealed that these two types of political connections whether individually or combined have negative, but statistically insignificant relationship with firm performance. However, column (5) which presents the result of government linked companies, shows that at 10 percent significant level, GLC type of connection has a positive effect on firm performance. This also concurs with the findings of Wong and Hooy (2018) [31] who found that GLCs significantly increases firm performance. This is true because GLCs have a more stable connections because of the presence of government ownership than other types of political connections. While political connections through shareholders and directors may not be stable because of changes in governments, it is however not always so with GLCs because the government shareholdings belong to the government not individuals. Politicians come and go, but the government remains, hence, it is not a surprise to see that only connections through the GLCs shows a significant positive effect on firm performance. 
Another interesting finding of the study shows that combining all the types of political connections gives a more significance level of 5 percent as opposed to that of political connection through GLCs alone which is only significant at 10 percent. It could therefore be augured that while GLCs positively affect firm performance, the effect becomes more significant with other types of political connections in place, but political connections through large shareholders and directors individually or both do not have any significant relationship with firm performance in the South African context. Lastly, the results also revealed a negative effect of firm size on firm performance at $10 \%$ significance level.

\section{Conclusion}

This study examines the relationship between political connections and firm performance using a firm-level panel data of 50 firms listed on JSE, with major attention given to dynamic relationship and types of political connections. The findings revealed that political connections have positive effect on firm performance, but such effect differs with type of political connections. Therefore political connections should be discouraged in private companies except for government linked companies which are encouraged to have more types of political connections for better performance.

\section{References}

1. Adhikari A, Derashid C, Zhang H. Public policy, political connections, and effective tax rates: Longitudinal evidence from Malaysia and cross-country evidence. Journal of Accounting and Public Policy. 2006; 25(5):574-595.

2. Arellano and Bond. Some Tests of Specification for Panel Data: Monte Carlo Evidence and an Application to Employment Equations. The Review of Economic Studies. 1991; 58(2):277-297. https://doi.org/10.2307/2297968

3. Boubakri N, Cosset JC, Saffar W. The impact of political connections on firms operational performance and financing decision. Journal of Financial Research. 2012; 35(3):397-423. https://doi.org/10.1111/j.14756803.2012.01322.x

4. Boubakri N, Cosset JC, Saffar W. The impact of political connections on firms operating performance and financing decisions. Journal of Financial Research. 2012; 35(3):397-423. doi:10.1111/jfir.2012.35.issue-3.

5. Business Insider SA. The biggest South African business scandals over the past decade, 2020. https://www.businessinsider.co.za/the-top-southafrican-business-scandals-the-past-decade-2020-1 retrieved on 29th August 2020.

6. Cao X, Lemmon M, Pan X, Qian M, Tian G. Political Promotion, CEO Incentives, and the Relationship between Pay and Performance. Management Science, 2018. https://doi:10.1287/mnsc.2017.2966.

7. Chen HK, Liao YC, Lin CY, Yen JF. The effect of the political connections of government bank CEOs on bank performance during the financial crisis. Journal of Financial Stability, 2018, 36, DOI:10.1016/j.jfs.2018.02.010

8. Chung C, Byun J, Young J. Corporate Political Ties and Firm Value: Comparative Analysis in the Korean Market. Sustainability. 2019; 11(2):327. https://doi:10.3390/su11020327.
9. Claessens S, Feijen E, Laeven L. Political connections and preferential access to finance: The role of campaign contributions. Journal of Financial Economics. 2008; 88(3):554-580. https://doi:10.1016/j.jfineco.2006.11.003.

10. Danjuma, Nadiyasu. Relationship between profitability and growth of the quoted non-financial firms: Evidence from Nigeria. International Journal of Financial Management and Economics. 2020; 3(2):01-07.

11. Faccio M. Politically Connected Firms. American Economic Review. 2006; 96(1):369-386. https://doi.rg/10.1257/000282806776157704

12. Faccio M, Masulis RW, McConnell J. Political connections and corporate bailouts. The Journal of Finance. 2006; 61(6):2597-2635.

13. Firth M, Rui OM, Wu W. The Effects of Political Connections and State Ownership on Corporate Litigation in China. The Journal of Law and Economics. 2011; 54(3):573-607. https://doi:10.1086/659261.

14. Guo Li, Zhong. Political involvement and firm performance - Chinese setting and cross-country evidence J Int. Financ. Markets Inst. Money. 2019; 59:218-231.

15. Hung CHD, Jiang Y, Liu FH, Tu H, Wang S. Bank political connections and performance in China. Journal of Financial Stability. 2017; 32:57-69. https://doi:10.1016/j.jfs.2017.09.003.

16. Hung M, Kim Y, Li SJ. Political connections and voluntary disclosure: Evidence from around the world: Journal of International Business Studies. 2018; 49(272). https://doi.org/10.1057/s41267-017-0139-z.

17. Kuo L, Yu HC. Corporate political activity and environmental sustainability disclosure. Baltic Journal of Management. 2017; 12(3):348-367.

https://doi:10.1108/bjm-07-2016-0149.

18. Li H, Meng L, Wang Q, Zhou LA. Political connections, financing and firm performance: Evidence from Chinese private firms. Journal of Development Economics. 2008; 87(2008):283-29. https://doi.org/10.1016/j.jdeveco.2007.03.001

19. Ling L, Zhou X, Liang Q, Song P, Zeng H. Political connections, overinvestments and firm performance: Evidence from Chinese listed real estate firms. Finance Research Letters. 2016; 18:328-333. https://doi.org/10.1016/j.frl.2016.05.009

20. Maaloul A, Chakroun R, Yahyaoui S. The effect of political connections on companies performance and value: Evidence from Tunisian companies after the revolution, Journal of Accounting in Emerging Economies. 2018; 8(2):185-204. https://doi.org/10.1108/JAEE-12-2016-0105

21. Muttakin MB, Monem RM, Khan A, Subramaniam N. Family firms, firm performance and political connections: Evidence from Bangladesh. Journal of Contemporary Accounting \& Economics. 2015; 11(3):215-230. https://doi:10.1016/j.jcae.2015.09.001.

22. Niessen A, Ruenzi S. Political Connectedness and Firm Performance: Evidence from Germany. German Economic Review. 2009; 11(4):441-464. https://doi:10.1111/j.1468-0475.2009.00482.x.

23. Omonona $\mathrm{S}$, Oni O. The relationship between political affiliation and performance of mobile telecommunication organisations in South Africa. 
Journal of Management Information and Decision Sciences. 2019; 22(3):284-295.

24. Pfeffer J, Salancik GR. The External Control of Organizations: A Resource Dependence Perspective. University of Illinois at Urbana-Champaign's Academy for Entrepreneurial Leadership Historical Research Reference in Entrepreneurship. Available at, 1978. SSRN: https://ssrn.com/abstract=1496213.

25. Rabia N. How Does Political Connection Impact the Firm Performance? Austin Journal of Business Administration and Management. 2020; 4(1):1044.

26. Roodman D. How to do Xtabond2: An Introduction to Difference and System GMM in Stata. The Stata Journal: Promoting Communications on Statistics and Stata. 2009; 9(1):86-136. Doi:10.1177/1536867x0900900106.

27. Saeed A, Belghitar Y, Clark E. Political Connections and Leverage: Firm-level Evidence from Pakistan. Managerial and Decision Economics. 2014; 36(6):364383. https://doi:10.1002/mde.2674.

28. Sami P, Rahnavard F, Alavi Tabar A. The effect of political and business ties on firm performance. Management Research Review, 2019. doi:10.1108/mrr12-2017-0439

29. Shleifer Andrei, Vishny R. The Grabbing Hand. Harvard University Press, 1998.

30. Sojli E, Tham WW. Foreign political connections. Journal of International Business Studies. 2017; 48(2):244-266. https://doi:10.1057/s41267-016-0059-3.

31. Wong WY, Hooy CW. Do types of political connection affect firm performance differently? Pacific-Basin Finance Journal. 2018; 51:297-317. Accepted manuscript. https://doi:10.1016/j.pacfin.2018.08.009.

32. Wu H, Li S, Ying SX, Chen X. Politically connected CEOs, firm performance, and CEO pay. Journal of Business Research. 2018; 91:169-180. https://doi:10.1016/j.jbusres.2018.06.003.

33. Wu Wu, Wu C, Zhou C, Wu J. Political connections, tax benefits and firm performance: Evidence from China. Journal of Accounting and Public Policy. 2012; 31(3):277-300. https://doi:10.1016/j.jaccpubpol.2011.10.005.

34. Zhang H, Li L, Zhou D, Zhou P. Political connections, government subsidies and firm financial performance: Evidence from renewable energy manufacturing in China. Renewable Energy. 2014; 63:330-336. https://doi:10.1016/j.renene.2013.09.029.

35. Zhang L, Ye F, Yang L, Zhou G. Impact of Political Connections on Corporate Environmental Performance from a Green Development Perspective. Sustainability. 2019; 11(5):1317. https://doi:10.3390/su11051317. 